\title{
Pengaruh Kepemimpinan dan Disiplin Kerja terhadap Kinerja Pegawai pada Dinas Pendidikan Kota Banjarmasin
}

\author{
Eva Amalia ${ }^{1}$, Muhammad Rudiansyah ${ }^{2}$ \\ ${ }^{12}$ Sekolah Tinggi Ilmu Manajemen Indonesia (STIMI) Banjarmasin \\ Email : rudibanper@gmail.com
}

\begin{abstract}
This study aims to determine the effect of leadership and work discipline partially, and the effect of leadership and work discipline simultaneously on employee performance at Dinas Pendidikan Kota Banjarmasin.

This research uses quantitative methods. The data used in this study consisted of primary data and secondary data. The population of this research is the employees of Dinas Pendidikan Kota Banjarmasin, amounting to 102 people. Sampling uses probability sampling. The technique of data collection was carried out by distributing questionnaires to 51 respondents from Dinas Pendidikan Kota Banjarmasin employees who were obtained using the Slovin formula. The data analysis technique used is multiple linear regression to determine the effect of leadership and work discipline on performance in Dinas Pendidikan Kota Banjarmasin using Statistical Package for the Social Science (SPSS) version 21.00 for windows.

The results of the study concluded that the leadership and work discipline variables partially affect the performance of employees at the Banjarmasin City Education Office. The results of the study concluded that the variables of leadership and work discipline simultaneously affect the performance of employees at Dinas Pendidikan Kota Banjarmasin.
\end{abstract}

Keywords : Leadership, Work Discipline, Employee Performance

Abstrak

Penelitian ini bertujuan untuk mengetahui pengaruh kepemimpinan dan disiplin kerja secara parsial, dan pengaruh kepemimpinan dan disiplin kerja secara simultan terhadap kinerja pegawai pada Dinas Pendidikan Kota Banjarmasin.

Penelitian ini menggunakan metode kuantitatif. Data yang digunakan dalam penelitian ini terdiri dari data primer dan data sekunder. Populasi penelitian ini adalah pegawai Dinas Pendidikan Kota Banjarmasin yang berjumlah 102 orang. Pengambilan sampel menggunakan probability sampling. Teknik pengumpulan data dilakukan dengan menyebarkan kuesioner kepada responden sebanyak 51 orang pegawai Dinas Pendidikan Kota Banjarmasin yang di dapatkan dengan menggunakan rumus Slovin. Teknik analisa data yang digunakan regresi linear berganda untuk mengetahui pengaruh kepemimpinan dan disiplin kerja terhadap kinerja pada Dinas Pendidikan Kota Banjarmasin dengan menggunakan Statistical Package for the Social Science (SPSS) versi 21.00 for windows.

Hasil penelitian menyimpulkan bahwa variabel kepemimpinan dan disiplin kerja secara parsial berpengaruh terhadap kinerja pegawai pada Dinas Pendidikan Kota Banjarmasin. Hasil penelitian menyimpulkan bahwa variabel kepemimpinan dan disiplin kerja secara simultan berpengaruh terhadap kinerja pegawai pada Dinas Pendidikan Kota Banjarmasin.

Kata Kunci : Kepemimpinan, Disiplin Kerja, Kinerja Pegawai

(C) 2019 Jurnal Riset Inspirasi Manajemen dan Kewirausahaan

\section{PENDAHULUAN}

\section{Latar Belakang}

Sumber daya manusia (SDM) dalam organisasi pada saat ini semakin diperhatikan dalam setiap kegiatan, terutama yang diarahkan untuk mencapai tujuan organisasi. Sumber daya manusia mencakup keseluruhan manusia dalam suatu organisasi yang terlibat dalam kegiatan operasional organisasi tersebut mulai dari level yang paling bawah (lower management) hingga level yang berada paling atas (top management). Walaupun berbeda levelnya tetapi semua elemen sumber daya manusia tersebut memiliki peran yang sama terhadap tercapainya tujuan organisasi.

Menurut Fathoni (2014 : 22) organisasi adalah suatu proses perencanaan atau pola hubungan dalam suatu kerja kelompok yang pada dasarnya digunakan sebagai tempat kerjasama secara terencana, terorganisasi, dan terpimpin dalam sumber daya manusia. Organisasi memerlukan sumber daya manusia sebagai pengelola sistem untuk mencapai tujuannya. Agar sistem yang dibuat dapat berjalan dengan baik maka harus memperhatikan aspek-aspek penting dalam 
pengelolaanya seperti disiplin kerja, kepemimpinan, kinerja, serta aspek-aspek lainnya. hal ini akan menjadikan manajemen sumber daya manusia menjadi salah satu indikator yang penting untuk mencapai tujuan organisasi secara efektif dan efisien.

Kinerja secara umum merupakan gambaran prestasi yang dicapai suatu organisasi maupun perusahaan dalam kegiatan operasionalnya. Suatu organisasi memerlukan sumber daya manusia sebagai pendukung utama untuk mencapai tujuan organisasi yang telah ditetapkan. Sumber daya manusia yang berkualitas akan mampu memajukan organisasi dalam peningkatan produktivitas kerja.

Kinerja merupakan hasil kerja secara kualitas dan kuantitas yang dicapai oleh seorang pegawai dalam melaksanakan tugasnya sesuai dengan tanggung jawab yang diberikan kepadanya Dan juga gambaran mengenai tingkat pencapaian pelaksanaan suatu program kegiatan atau kebijakan dalam mewujudkan sasaran, tujuan, visi, dan misi organisasi yang dituangkan melalui perencanaan strategis suatu organisasi (Moehirono, dalam Isvandiari, 2017 : 95). Pendukung utama untuk mencapai tujuan organisasi yaitu menunjukkan kerapihan dan ketelitian hasil kerja dengan tidak mengabaikan volume pekerjaan, menunjukkan banyaknya jumlah jenis pekerjaan yang dilakukan dalam suatu waktu sehingga efisien dan efektifitas dapat terlaksana sesuai dengan tujuan, ketersediaan pegawai untuk berpartisipasi dengan pegawai yang lain secara vertikal dan horizontal baik di dalam maupun di luar pekerjaan sehingga pekerjaan akan semakin baik, menunjukkan seberapa besar pegawai dalam menerima melaksanakan pekerjaannya dan mempertanggung jawabkan hasil kerja, dan adanya inisiatif dari dalam diri anggota organisasi untuk melakukan pekerjaan serta mengatasi masalah dalam pekerjaan tanpa menunggu perintah.

Salah satu hal yang mempengaruhi kinerja adalah kepemimpinan dalam suatu organisasi. Menurut Soekarso (2015:60), kepemimpinan adalah suatu proses mempengaruhi perilaku anggota dan sumber daya secara efektif dan efisien kearah pencapaian tujuan secara bersama. Pada dinas pendidikan kota banjarmasin yang mempengaruhi keberhasilan kepemimpinan yaitu kemampuan dalam kedudukannya sebagai pengawas atau pelaksana fungsi-fungsi dasar manajemen, kebutuhan akan prestasi kerja dalam pekerjaan mencakup pencarian tanggung jawab dan keinginan sukses, kecerdasan mencakup kebijakan pemikiran kreatif dan daya pikir, ketegasan atau kemampuan untuk membuat keputusan-keputusan dan memecahkan masalah dengan cepat dan tepat, dan kepercayaan diri atau pandangan terhadap dirinya sehingga mampu memecahkan masalah.

Faktor lain yang mempengaruhi kinerja adalah disiplin kerja karena tanpa adanya disiplin kerja, setiap kegiatan yang dilakukan akan mendapatkan hasil yang kurang memuaskan dan tidak sesuai dengan yang diharapkan. Menurut Afandi (2016 :1), disiplin kerja yaitu suatu tertib atau peraturan yang dibuat untuk mengubah suatu perilaku serta sebagai suatu upaya untuk meningkatkan kesadaran dan kesediaan seseorang mentaati semua peraraturan dan norma-norma sosial yang berlaku, tanpa adanya sikap disiplin untuk pencapaian tujuan dalam organisasi yang diinginkan. kedisiplinan harus ditegakkan karena tanpa ada disiplin pegawai yang baik sulit bagi organisasi untuk mencapai tujuannya. Jadi, kedisiplinan adalah kunci keberhasilan suatu organisasi untuk mencapai tujuannya. Adapun faktor yang mempengaruhi disiplin kerja pada dinas pendidikan yaitu tujuan yang akan dicapai harus jelas dan ditetapkan secara ideal serta cukup menantang bagi kemampuan pegawai, teladan pimpinan sangat berperan dalam menentukan kedisiplinan pegawai karena pimpinan dijadikan teladan dan panutan oleh para bawahannya, balas jasa turut mempengaruhi kedisiplinan pegawai karena balas jasa akan memberikan kepuasaan dan kecintaan pegawai terhadap pekerjaannya, keadilan turut mendorong terwujudnya kedisiplinan pegawai, waskat (pengawasan melekat) tindakan nyata dan paling efektif dalam mewujudkan kedisiplinan, sanksi hukuman berperan penting dalam memelihara kedisiplinan pegawai dan hubungan kemanusiaan yang harmonis diantara sesama pegawai.

Dinas Pendidikan merupakan suatu instansi pemerintah yang berperan dalam mengembangkan, meningkatkan kualitas dan mengkoordinasikan unsur pendidikan. Di lembaga inilah aktifitas para pegawai diharapkan mampu berperan dalam mewujudkan suatu pola pendidikan serta mampu mengatasi segala permasalahan yang berhubungan dengan kualitas pendidikan Kantor Dinas Pendidikan Kota Banjarmasin merupakan salah satu institusi pendidikan ditingkat daerah Kota Banjarmasin yang bertanggung jawab dalam mengembangkan, meningkatkan kualitas dan mengkoordinasi unsur pendidikan di lingkup kota Banjarmasin . Di instansi atau lembaga inilah semestinya para pegawai Kantor Dinas Pendidikan Kota Banjarmasin bekerja secara optimal demi kemajuan kualitas pendidikan di tingkat kota Banjarmasin

\section{Rumusan Masalah}

Berdasarkan latar belakang yang dikemukakan, maka rumusan masalah yang akan diteliti dapat dirumuskan sebagai berikut :

1. Apakah kepemimpinan dan disiplin kerja berpengaruh terhadap kinerja pegawai pada Dinas Pendidikan Kota Banjamasin? 
2. Apakah kepemimpinan berpengaruh terhadap kinerja pegawai pada Dinas Pendidikan Kota Banjarmasin?

3. Apakah disiplin kerja berpengaruh terhadap kinerja pegawai pada Dinas Pendidikan Kota Banjarmasin?

\section{Tujuan Penelitian}

1. Untuk mengetahui pengaruh disiplin kerja terhadap kinerja pegawai pada Dinas Pendidikan Kota Banjarmasin.

2. Untuk mengetahui pengaruh kepemimpinan terhadap kinerja pegawaai pada Dinas Pendidikan Kota Banjarmasin.

3. Untuk mengetahui pengaruh kepemimpinan dan disiplin kerja terhadap kinerja pegawai pada Dinas Pendidikan Kota Banjarmasin.

\section{KAJIAN LITERATUR}

\section{Kepemimpinan}

Kepemimpinan adalah kemampuan untuk mempengaruhi dan membujuk orang lain untuk mengambil langkah dalam mencapai tujuan dan sasaran bersama (Handoko, 2014:292). Seseorang tidak dapat menjadi pemimpinan tanpa sekelompok orang yang mengikuti pengarahan dan menaruh percayaan kepada pemimpin. Pemimpinan memiliki tanggung jawab terhadap karyawan, kelompok, organisasi, atau tim untuk memimpin dengan adil dan etis. Untuk menjadi pemimpin yang baik perlu memperkuat diri dengan mengikuti tren-tren kepemimpinan terkini, mengamati pemimpinpemimpin lain dan menyadari bahwa gaya kepemimpinan mempengaruhi kinerja karyawan.

Indikator perilaku kepemimpinan menurut Ghiselli (dalam Puteri, 2017) yaitu sebagai berikut:

1. Kemampuan sebagai pengawas.

2. Kebutuhan akan prestasi dalam pekerjaan.

3. Ketegasan.

4. Kecerdasan.

5. Kepercayaan diri

\section{Disiplin Kerja}

Menurut Fathoni (2014:172), mengatakan disiplin adalah sikap kesediaan dan kerelaan seseorang untuk mematuhi dan menaati normanorma peraturan yang berlaku disekitarnya. Disiplin karyawan yang baik akan mempercepat tujuan perusahaan, sedangkan disiplin yang merosot akan menjadi penghalang dan memperlambat pencapaian tujuan perusahaan.

Indikator disiplin kerja menurut Hasibuan ( 2014 : 194), yaitu sebagai berikut:

1. Tujuan dan kemampuan.

Tujuan yang akan dicapai harus jelas dan ditetapkan secara ideal serta cukup menantang bagi kemampuah karyawan.
2. Teladan pimpinan.

Teladan pimpinan sangat berperan dalam menentukan kedisiplinan karyawan, karena pimpinan dijadikan teladan dan panutan oleh para bawahannya.

3. Balas jasa.

Balas jasa (gaji dan kesejahteraan) turut mempengaruhi kedisiplinan karyawan karena balas jasa akan memberikan kepuasan dan kecintaan karyawan terhadap perusahaan dan pekerjaannya.

4. Keadilan.

Keadilan turut mendorong terwujudnya kedisiplinan karyawan.

5. Ketegasan.

Ketegasan pimpinan dalam melakukan tindakan akan mempengaruhi kediplinan karyawan.

6. Waskat

Waskat (pengawasan melekat) adalah tindakan nyata dan palin efektif dalam mewujudkan kedisiplinan karyawan.

7. Sanksi Hukuman

Sanksi hukuman berperan penting dalam memelihara kedisiplinan karyawan.

8. Hubungan Kemanusian

Hubungan kemanusian yang harmonis diantara sesama karyawan.

Kinerja

Kinerja merupakan singkatan dari kinetika energi kerja yang padanannya dalam bahasa inggris adalah performance. Kinerja adalah keluaran yang dihasilkan oleh fungsi-fungsi atau indikatorindikator suatu pekerjaan atau suatu profesi dalam waktu tertentu (Wirawan, 2015: 5). Menurut Anwar Prabu Mangkunegara (2014: 09), kinerja adalah hasil kerja secara kualitas dan kuantitas yang dicapai oleh seorang karyawan dalam melaksanakan tugasnya sesuai dengan tanggung jawab yang diberikan kepadanya.

Indikator kinerja karyawan menurut Mang kunegara ( $2015: 67)$ adalah sebagai berikut :

1. Kualitas Kerja

Menunjukkan kerapihan, ketelitian, keterkaitan hasil kerja dengan tidak mengabaikan volume pekerjaan.

2. Kuantitas Kerja

Menunjukkan banyaknya jumlah jenis pekerjaan yang dilakukan dalam suatu waktu sehingga efisiensi dan efektifitas dapat terlaksana sesuai dengan tujuan perusahaan.

3. Kerjasama

Kesediaan karyawan untuk berpatisipasi dengan karyawan yang lain secara vertikal dan horizontal baik di dalam maupun di luar pekerjaan sehingga pekerjaan akan semakin baik. 
4. Tanggung Jawab

Menunjukkan seberapa besar karyawan dalam menerima dan melaksanakan pekerjaannya, mempertanggung jawabkan hasil kerja serta sarana dan prasarana yang digunakan dan perilaku kerjanya setiap hari.

5. Inisiatif

Adanya inisiatif dari dalam diri anggota organisasi untuk melakukan pekerjaan serta mengatasi masalah dalam pekerjaan tanpa menunggu perintah.

\section{METODE PENELITIAN}

\section{Jenis Data dan Sumber Data}

Jenis data yang diperlukan dalam penelitian ini terdiri dari :

1. Data Primer

Data primer adalah merupakan data yang diperoleh secara langsung dari responden dengan menggunakan daftar koesioner terstruktur yang berisikan bagaimana tanggapan responden terhadap pertanyaanpertanyaan yang berhubungan dengan kepemimpinan, disiplin kerja serta kinerja pegawai.

2. Data Sekunder

Data sekunder adalah sebagai pelengkap guna menunjang data primer, yakni sejarah perusahaan, struktur organisasi serta sarana prasarana.

\section{Instrumen Penelitian}

Dimaksud Instrumen penelitian adalah alat yang digunakan untuk pengukuran terhadap variabel-variabel yang diteliti. Mengingat gejalagejala yang ada berkaitan dengan Kepemimpinan, Disiplin Kerja serta Kinerja Pegawai lebih banyak menunjukkan suatu sikap, maka pengukuran menggunakan Skala Likert yaitu skor yang digunakan 1 s.d. 5 yang diterapkan secara bervariasi menurut masing-masing kategori pertanyaan, sehingga masing-masing pertanyaan 5 pilihan saja. Agar penelitian yang akan dilakukan menghasilkan data yang dapat dipercaya kebenarannya, maka instrument yang digunakan dalam penelitian harus terlebih dahulu diuji validitas dan reliabilitasnya.

\section{Populasi dan Sampel}

Populasi adalah wilayah generalisasi yang terdiri atas: obyek/subyek yang mempunyai kuantitas dan karakteristik tertentu yang ditetapkan oleh peneliti untuk dipelajari dan kemudian ditarik kesimpulannya (Sugiyono, 2014:148). Dalam penelitian ini populasi pegawai Dinas Pendidikan Kota Banjarmasin sebanyak 102 orang.

Sample adalah bagian dari jumlah dan karakteristik yang dimiliki populasi tersebut (Sugiyono,
2014:149). Dalam penelitian ini pengukuran sampel merupakan suatu langkah untuk menentukan besarnya sampel yang diambil dalam melaksanakan suatu penelitian.

Untuk menghitung penentuan jumlah sampel dari populasi tertentu, maka digunakan rumus Slovin sebagai berikut :

Rumus Slovin

$n=\frac{N}{1+N e^{2}}$

Keterangan :

$\mathrm{n}=$ Jumlah Sampel

$\mathrm{N}=$ Jumlah Populasi

$\mathrm{e}=$ Batas Toleransi Kesalahan (error tolerance)

Jumlah populasi adalah 102, dan tingkat kesalahan yang dikehendaki adalah 10\%, maka jumlah sampel yang digunakan adalah :

$N=\frac{102}{1+102(0.10)^{2}}$
$N=50.50$ dibulatkan menjadi 51

Teknik Pengumpulan Data

1. Observasi yaitu pengumpulan data dengan cara melakukan pengamatan secara langsung terhadap objek yang diteliti.

2. Interview yaitu pengumpulan data dengan cara mengadakan komunikasi secara langsung antara peneliti dengan seseorang atau lebih yang berada dalam objek yang diteliti sebagai sumber data.

3. Kuesioner yaitu seperangkat pertanyaan yang disusun untuk diajukan kepada responden yang berbentuk pertanyaan tertulis. Data yang digunakan dalam penelitian ini adalah berupa data yang dikumpulkan atas 51 orang pegawai dinas pendidikan kota Banjarmasin melalui penyampaian kuesioner kepada responden.

\section{Teknik Analisa Data}

Untuk membuktikan hipotesis yang telah diajukan, maka digunakan metode analisis sebagai berikut :

1. Analisa deskriptif adalah suatu analisis yang menggunakan statisik deskriptif, seperti ratarata dan standar deviasi. Analisis ini digunakan untuk memperoleh gambaran mengenai kepemimpinan, disiplin kerja terhadap kinerja pegawai dinas pendidikan kota Banjarmasin.

2. Analisa regresi linier berganda yaitu suatu analisis yang bertujuan untuk menguji pengaruh kepemimpinan, disiplin kerja terhadap kinerja pegawai dinas pendidikan kota Banjarmasin. Dengan menggunakan rumus regresi linear berganda yang dikutip dari buku Mulyono (2006 : 257) yaitu :

$\mathrm{Y}=\mathrm{b}_{0}+\mathrm{b}_{1} \mathrm{X}_{1}+\mathrm{b}_{2} \mathrm{X}_{2}+\mathrm{b}_{3} \mathrm{X}_{3}+\mathrm{e}$

Di mana :

$\mathrm{Y}$ = kinerja pegawai

$\mathrm{X}_{1}=$ Kopemimpinan

$\mathrm{X}_{2}=$ Disiplin Kerja 
$\mathrm{e} \quad=$ Pengganggu (error)

a $=$ Konstanta

$\mathrm{b}_{1}, \mathrm{~b}_{2}=$ Koefisien regresi yang hendak diamati.

Agar model regresi tersebut dapt digunakan untuk estimasi, maka harus memeuhi asumsi klasik, karena menurut Gujarati (1995:153), apabila asumsi klasik tidak dilanggar, maka estimator OLS (Ordinary Least Square ) akan BLUE (Best Linier Unbiased Estimator), artinya estimator tersebut bias dan mempunyai varians yang minimum.Asumsi klasik yang dianggap penting untuk diuji adalah Uji multikolinieritas, Uji heteroskedastisitas dan Uji Normalitas.

3. Uji Parsial (Uji t) untuk pengujian hipotesis pertama

Uji ini adalah untuk mengetahui apakah pengaruh masing-masing variabel bebas terhadap variabel terikat apakah bermakna atau tidak. Pengujian dilakukan dengan membandingkan antara nilai $t_{\text {hitung masing- }}$ masing variabel bebas dengan nilai $t_{\text {tabel }}$ dengan derajat kesalahan $5 \%$ dalam arti $(\alpha=0.05)$. Apabila nilai $t_{\text {hitung }} \geq t_{\text {tabel }}$, maka variabel bebasnya memberikan pengaruh bermakna terhadap variabel terikat.

4. Uji serempak ( Uji F) untuk pengujian hipotesis kedua

Uji ini digunakan untuk mengetahui apakah seluruh variabel bebasnya secara bersamasama mempunyai pengaruh yang bermakna terhadap variabel terikat. Pengujian dilakukan dengan membandingkan nilai $\mathrm{F}_{\text {hitung }}$ dengan $\mathrm{F}_{\text {tabel }}$ pada derajat kesalahan $5 \%$ dalam arti $(\alpha=$ $0.05)$. Apabila nilai $F_{\text {hitung }} \geq$ dari nilai $F_{\text {tabel }}$, maka berarti variabel bebasnya secara bersama-sama memberikan pengaruh yang bermakna terhadap variabel terikat atau hipotesis pertama sehingga dapat diterima.

Selanjutnya untuk melihat sumbangan variabel bebas dalam menerangkan variabel teriakat, dapat diketahui dari besarnya koefesien ditermenasi (R2). Jika R2 yang diproleh dari hasil perhitungan semakin besar (mendekati satu) maka dapat dikatakan bahwa sumbangan dari variabel bebas terhadap variabel terikat semakin besar, demikian juga sebaliknya. Untuk melakukan perhitungan regresi linier berganda dan uji-uji tersebut digunakan bantuan kompoter dengan program SPSS Windows Versi 21.

\section{HASIL PENELITIAN DAN PEMBAHASAN}

\section{Uji Validitas}

Uji validitas dilakukan dengan tehnik Product Moment dari masing-masing item terhadap nilai total factor. Untuk membuktikan valid tidaknya suatu item instrument penelitian, sebagaimana ketentuan dalam syarat minimum dianggap memenuhi syarat adalah apabila $r>0,30$. Dengan demikian apabila korelasi antar butir dengan skor total < 0,30, maka butir dalam instrument tersebut dinyatakan tidak valid (Sugiono, 1999).

Sejumlah 33 item instrument penelitian yang disertakan dalam pengujian validitas, yaitu variabel Kepemimpinan sebanyak 15 item, variabel disiplin kerja sebanyak 8 item, variabel kinerja pegawai sebanyak 10 item.

Dari hasil menunjukkan bahwa untuk uji validitas instrument variabel Kepemimpinan (X1) sebanyak 15 item pertanyaan semuanya valid, untuk instrumen penelitian variabel disiplin kerja (X2) sebanyak 8 item pertanyaan semuanya valid, dan untuk variabel kinerja pegawai sebanyak 10 item pertanyaan semuanya juga valid, karena nilai yang disyaratkan dari hasil korelasi $r>0,30$.

\section{Uji Reliabilitas}

Hasil uji reliabilitas instrument penelitian menggunakan skala bertingkat (rating scal) dengan formulasi Alpha Cronbach. Kriteria yang digunakan untuk menentukan kuesioner penelitian ini memenuhi reliabilitas adalah jika nilai Cronbach Alpha > 0,70 (Ghozali, 2016 : 52).

Hasil uji reliabilitas koesioner terdapat nilai Cronbash's Alpha variabel Kepemimpinan (X1) sebesar 0,916, disiplin kerja (X2) sebesar 0,886, dan kinerja pegawai (Y) sebesar 0,838. Nilai Cronbah's Alpha semua kuesioner tersebut $>0,70$. Dengan demikian kuesioner ini dikatakan reliabel dan dapat dipergunakan untuk mengumpulkan data penelitian.

\section{Hasil Uji Asumsi Klasik}

\section{Uji Normalitas}

Uji normalitas bertujuan untuk menguji apakah dalam model regresi, variabel residual memiliki distribusi normal atau tidak (Ghozali, 2016:154). Pengujian normalitas dilakukkan dengan uji normal probability plot. Regresi memenuhi asumsi jika data menyebar disekitar garis diagonal dan mengikuti arah garis diagonal atau grafik histogramnya menunjukkan pola distribusi normal. Hasil dari uji normalitas dengan menggunakan program SPSS adalah sebagai berikut : 


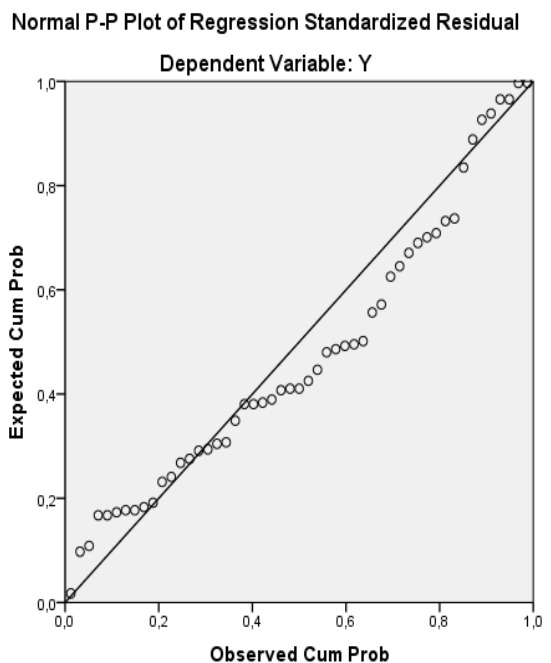

Gambar Kurva Normal P-Plot

Pada Kurva Normal P-plot diatas dapat dilihat bahwa penyebaran titik-titik di sekitar garis masih mengikuti garis lurus dan tidak melebar terlalu jauh. Maka dapat disimpulkan bahwa data penelitian berdistribusi normal.

\section{Uji Multikolonieritas}

Uji muktikolinieritas bertujuan untuk menguji tingkat keeratan tingkat asosiasi hubungan atau pengaruh antar variabel bebas (independen) melalui besaran koefisien korelasi. Untuk mendeteksi ada tidaknya multikolinieritas yaitu dengan melihat nilai VIF (Variance Inflation Factor) dan nilai tolerance. Model regresi dikatakan bebas dari multikolinieritas apabila nilai $\mathrm{VIF} \leq 10$, dan nilai tolerance $\geq 0,1$ ( Ghozali, 2016: 103). Hasil uji multikolinieritas VIF dan tolerance dapat dilihat sebagai berikut :

Tabel Hasil Uji Multikolinieritas

\begin{tabular}{lcc}
\hline \multicolumn{1}{c}{ Variabel } & Tolerance & VIF \\
\hline Kepemimpinan & 0,919 & 1,088 \\
\hline Disiplin Kerja & 0,919 & 1,088
\end{tabular}

Sumber : Hasil Pengolahan Data Penelitian tahun 2019

Hasil perhitungan dari nilai tolerance kepemimpinan dan disiplin kerja adalah sebesar 0,919. Maka dapat disimpulkan bahwa tidak ada multikolinieritas dari nilai tolerance karena memiliki nilai lebih besar dari 0,10. Dilihat dari nilai VIF kepemimpinan dan disiplin kerja adalah sebesar 1,088. Ini menunjukkan tidak ada satu pun variabel independen yang memiliki nilai $\mathrm{VIF} \geq 10$. Jadi dapat disimpulkan bahwa tidak ada multikolinieritas antar variabel independen dalam model regresi.
3. Uji Heteroskedastisitas

Uji heteroskeastisitas bertujuan untuk menguji sama atau tidak varians dari residual yang satu dengan observasi lain. Jika residual mempunyai varians yang sama, maka disebut terjadi homokedastisitas dan jika varians tidak sama disebut heteroskedastisitas. Tidak terjadi heteroskedastisitas jika pada scatterplot titiktitik hasil pemgolahan data antara ZPERD (sumbu $\mathrm{X}=\mathrm{Y}$ hasil prediksi) dan SRESID (sumbu $\mathrm{Y}=\mathrm{Y}$ prediksi $\mathrm{Y}$ rill) menyebar dibawah atau diatas titik angka 0 pada sumbu Y tidak mempunyai pola yang teratur (Ghozali, 2016:134).

Gambar Hasil Uji Heteroskedastisitas

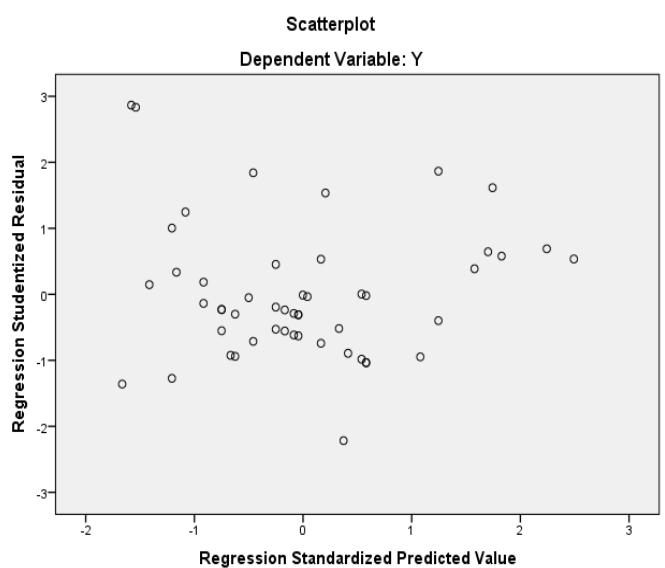

Berdasarkan hasil uji heteroskedastisitas diatas bahwa titik-titik menyebar secara acak diatas dan dibawahah titik nol pada sumbu Y, maka dapat disimpulkan tidak terjadi heteroskedastisitas pada model regresi.

\section{Analisis Regresi Linier Berganda}

Hasil uji regresi linier berganda dapat dilihat pada rekapitulasi sebagai berikut :

Rekapitulasi Hasil Uji Regresi Linier Berganda

\begin{tabular}{lcccc}
\hline $\begin{array}{c}\text { Variabel Bebas } \\
(\mathrm{X})\end{array}$ & $\begin{array}{c}\text { Koefisien } \\
\text { Regresi }\end{array}$ & $\begin{array}{c}\text { Koefisien } \\
\text { Beta }\end{array}$ & T hitung & $\begin{array}{c}\text { Probabilitas } \\
\text { (Sig) }\end{array}$ \\
\hline Kepemimpinan $(\mathrm{X} 1)$ & 0,293 & 0,314 & 2,400 & 0,020 \\
\hline Disiplin Kerja (X2) & 0,512 & 0,301 & 2,297 & 0,026 \\
\hline Konstanta & 6,469 & & & \\
F Hitung & 7,703 & & & \\
$\mathrm{R}$ & 0,493 & & & \\
$\mathrm{R}^{2}$ & 0,243 & & & \\
Adjusted R ${ }^{2}$ & 0,211 & & & \\
Sig. F & 0,001 & & & \\
SEE & 3,17190 & & & \\
\hline
\end{tabular}

Sumber : Hasil Pengolahan Data Penelitian tahun 2019

Berdasarkan rekapitulasi di atas dapat dilihat bahwa model regresi menunjukkan hasil yang signifikan dengan angka $F_{\text {hitung }}$, 
$\mathrm{F}_{\text {tabel }}$ yaitu $7,311>3,19$ dan nilai probabilitas (sig.) $\mathrm{F}<0,05$ yaitu $0,001<0,05$, sehingga model tersebut layak digunakan dalam analisis selanjutnya. Uji $\mathrm{F}$ pada dasarnya adalah membandingkan nilai $\mathrm{F}$ hasil perhitungan dengan nilai $\mathrm{F}$ menurut tabel. Bila nilai $\mathrm{F}$ hitung lebih besar dari pada nilai $\mathrm{F}$ tabel, maka kita menerima hipotesis alternatif yang menyatakan bahwa semua variabel independen secara simultan mempengaruhi varibel dependen ( Ghozali, 2016:98).

Nilai koefisien determinasi $\left(\mathrm{R}^{2}\right)$ pada penelitian ini adalah 0,243 , yang artinya variabel kepemimpinan (X1) dan disiplin kerja (X2) dapat menjelaskan variabel kinerja pegawai (Y) sebesar 24,3\%. Sedangkan selisih sisa sebesar $75,7 \%$ sisanya dijelaskan oleh variabel lain yang tidak digunakan dalam model ini.

Pada persamaan regresi linier berganda, angka Adjusted $R^{2}$ yang diperoleh sebesar 0,211 atau $21,1 \%$. Hal ini menujukkkan bahwa kepemimpinan (X1) dan disiplin kerja (X2) berpengaruh sebesar 21,1\% terhadap kinerja pegawai (Y) Dinas Pendidikan Kota Banjarmasin, sedangkan sisa selisih sebesar $78,9 \%$ dipengaruhi oleh variabel lain atau diluar penelitian ini.

Uji $t$ pada dasarnya menunjukkan seberapa jauh pengaruh satu variabel penjelas atau independen secara individual dalam menerangkan variabel dependen (Ghozali, 2016:97). Jika nilai signifikan $<0,05$ atau $t$ hitung > t tabel maka terdapat pengaruh variabel $\mathrm{X}$ terhadap variabel $\mathrm{Y}$. Jika nilai signifikan $>0,05$ atau $\mathrm{t}$ hitung $<\mathrm{t}$ tabel maka tidak terdapat pengaruh variabel $\mathrm{X}$ terhadap variabel $\mathrm{Y}$.

Dapat dilihat dari tabel di atas bahwa dilihat signifikan variabel kepemimpinan sebesar $0,020<0,05$ dan hasil $t_{\text {hitung }}>t_{\text {tabel }}$ yaitu untuk variabel kepemimpinan sebesar $2,400>2,010$ artinya terdapat pengaruh kepemimpinan terhadap kinerja pegawai. Sedangkan untuk variabel disiplin dapat dilihat signifikan sebesar $0,026<0,05$ dan hasil $t_{\text {hitung }}>t_{\text {tabel }}$ sebesar 2,297>2,010 yang artinya terdapat pengaruh disiplin kerja terhadap kinerja pegawai.

Persamaan yang dapat dibentuk dari tabel diatas sebagai berikut :

$\mathrm{Y}=\mathrm{a}+\mathrm{b} 1 \mathrm{X} 1+\mathrm{b} 2 \mathrm{X} 2+\mathrm{e}$

$\mathrm{Y}=6,469+0,293 \mathrm{X} 1+0,512 \mathrm{X} 2+\mathrm{e}$

Dari hasil perhitungan SPSS 21 diatas dapat disimpulkan sebagai berikut:

1. Konstanta sebesar 6,469 jika variabel kepemimpinan (X1) dan disiplin kerja (X2) adalah 0 maka kinerja pegawai nilainya 6,469 dengan asumsi variabel- variabel lain yang dapat mempengaruhi kineja pegawai dianggap tetap.

2. Koefisien regresi variabel kepemimpinan menyatakan bahwa setiap penambahan variabel kepemimpinan sebesar 1 satuan, maka terjadi penurunan kinerja karyawan sebesar 0,293 dengan asumsi variabel lain bernilai tetap.

3. Koefisien regresi variabel disiplin kerja 0,512 menyatakan bahwa setiap penambahan variabel disiplin kerja sebesar 1 satuan, maka terjadi kenaikan kinerja pegawai sebesar 0,512 dengan asumsi variabel lain bernilai tetap.

4. Uji $\mathrm{F}$ hasil signifikan $0,001<0,05$ dan hasil $F_{\text {hitung }}>F_{\text {tabel }}$ sebesar 7,703>3,19 bahwa variabel independen secara simultan mempengaruhi variabel dependen.

5. Uji $\mathrm{T}$ hasil signifikan variabel kepemimpinan sebesar $0,020<0,05$ dan hasil $t_{\text {hitung }}>\mathrm{t}_{\text {tabel }}$ yaitu untuk variabel kepemimpinan sebesar 2,400>2,010 artinya terdapat pengaruh kepemimpinan terhadap kinerja pegawai.

Untuk variabel disiplin dapat dilihat signifikan sebesar $0,026<0,05$ dan hasil $t_{\text {hitung }}>t_{\text {tabel }}$ sebesar 2,297>2,010 yang artinya terdapat pengaruh disiplin kerja terhadap kinerja pegawai.

\section{PENUTUP}

\section{Kesimpulan}

Berdasarkan kesimpulan dari hasil penelitian dan pembahasan mengenai pengaruh kepemimpinan dan disipilin kerja terhadap kinerja pegawai pada Dinas Pendidikan Kota Banjarmasin adalah sebagai berikut:

1. Hasil uji variabel kepemimpinan secara parsial berpengaruh signifikan terhadap kinerja pegawai pada Dinas Pendidikan Kota Banjarmasin.

2. Hasil uji variabel disiplin kerja secara parsial berpengaruh signifikan terhadap kinerja pegawai pada Dinas Pendidikan Kota Banjarmasin.

3. Hasil uji variabel kepemimpinan dan disiplin kerja secara simultan berpengaruh terhadap kinerja pegawai pada Dinas Pendidikan Kota Banjarmasin.

\section{Saran}

Berdasarkan hasil penelitian dan pembahasan mengenai pengaruh kepemimpinan dan disiplin kerja terhadap kinerja pegawai pada Dinas Pendidikan Kota Banjarmasin, maka beberapa saran yang bisa dikemukakan oleh penulis sebagai berikut: 
1. Bagi Dinas Pendidikan Kota Banjarmasin Dari hasil penelitian pada variabel kepemimpinan dan disiplin kerja berpengaruh positif dan signifikan terhadap kinerja pegawai. Artinya, kepemimpinan yang ada di Dinas pendidikan Kota Banjarmasin telah menjalankan apa yang semestinya dilakukan oleh pemimpin, yaitu berani menghadapi segala tugas dan tanggung jawabnya. Begitupun dengan pegawai yang sudah menerapkan disiplin kerja dengan baik. Maka dari itu, Dinas pendidikan Kota Banjarmasin perlu mempertahankan kepemimpinan dan disiplin kerja yang telah ada agar kinerja pegawai tetap baik dan terus meningkat.

2. Bagi Peneliti Selanjutnya

Bagi peneliti selanjutnya yang akan melakukan penelitia sejenis diharapkan agar menambahkan variabel lain yang kemungkinan berpengaruh terhadap kinerja pegawai pada Dinas Pendidikan Kota Banjarmasin selain dari kepemimpinan dan disiplin kerja. Agar penelitian tersebut dapat lebih dikembangkan.

\section{DAFTAR PUSTAKA}

Arifudin, Zainal. 2017. Pengaruh Kepemimpinan dan Disiplin Kerja Terhadap Kinerja Karyawan pada BPR Bank Daerah Kabupaten Kediri. Jurnal Simki Economic Vol. 01, No. 04.

Abdullah, M. Ma'ruf, 2016. Manajemen dan Evaluasi Kinerja Karyawan, Cetakan kedua, Yogyakarta : Aswaja Pressindo.

Afandi, Pandi, 2016. Manajemen Concept dan Indicator Human Resources Management. Edisi Pertama, Cetakan Pertama, Yogyakarta : Deepublish ( Grup Penerbitan CV Budi Utama).

Fathoni, H. Abdurrahmat. 2014. Organisasi dan Manajemen Sumber Daya Manusia, Cetakan Pertama, Jakarta : PT. Rineka Cipta.

Ghozali, Imam. "Aplikasi Analisis Multivariate dengan Program IBM SPSS 23", Universitas Diponegoro, Semarang, 2016.

Hasibuan, Malayu S.P. 2015. Manajemen Sumber Daya Manusia, Edisi Revisi. Jakarta : Bumi Aksara.

Handoko, T. Hani. 2014. Manajemen, Edisi Kedua, Cetakan Keduapuluh enam. Yogyakarta : BPFE.

Isvandiari, Any. 2017. Pengaruh Kepemimpinan dan Disiplin Kerja Terhadap Kinerja Karyawan Pada PT. Central Capital Futures Cabang Malang. Jurnal Jineka Vol. 12, No. 1, Hal. 17-22.
Mangkunegara, Anwar Prabu, 2014. Evaluasi Kinerja, cetakan ketujuh, Bandung : PT. Refika Aditama.

Mangkunegara, Anwar Prabu, 2015. Manajemen Sumber Daya Manusia, Cetakan Kedua Belas, Bandung : PT. Remaja Rosdakarya.

Rusvitawati, Devi. 2015. "Pengaruh Kompetensi Terhadap Kinerja Karyawan Rumah Sakit Sari Mulia Banjarmasin. Tesis tidak dipublikasikan. Banjarmasin: Program Pascasarjana Magister Manajemen, Universitas Lambung Mangkurat.

Sutrisno, H. Edy, 2017. Manajemen Sumber Daya manusia, Cetakan Kesembilan, Jakarta : Kencana.

Simamora, Henry, 2014. Manajemen Sumber Daya Manusia, Cetakan Kedua, Yogyakarta : Bagian Penerbit Sekolah Tinggi YKPN.

Soekarso, Iskandar Putong, 2015. Kepemimpinan Kajian Teoritis dan Praktis, Edisi Pertama. Jakarta : Erlangga.

Santosa, Priya. 2018." Evaluasi dan Strategi Peningkatan Kinerja Dinas Pendidikan, Pemuda, dan Olahraga Daerah Istimewa Yogyakarta". Tesis. Yogyakarta. Program Magister Manajemen. STIE Widya Wiwaha.

Sutikno, Sobry M. 2014. Pemimpin dan Gaya Kepemimpinan, Edisi Pertama, lombok : Holictica.

Sugiyono. "Metode Penelitian Kuantitatif, Kualitatif, dan R\&D”, Bandung, Alfabeta, 2014.

Thamrin. 2014. Perencanaan Manajemen Sumber Daya Manusia, Cetakan Pertama, Yogyakarta : Deepublish ( Grup Penerbitan CV Budi Utama).

Puteri, Dita Permata, 2017. "Pengaruh Kepemimpinan, Pendidikan, dan Komunikasi Terhadap Kinerja Karyawan di Klinik Spesialis Sari Mulia Banjarmasin". Skripsi. Fakultas Ekonomi dan Bisnis. Universitas Lambung mangkurat Banjarmasn.

Wibowo, 2017. Manajemen Kinerja, Edisi Kelima, Cetakan 12, Depok : PT. RajaGrafindo Persada.

Wijaya, Agus, 2015. Kepemimpinan Berkarakter, Edisi Revisi, Sidoarjo : Brilian Internasional.

Wirawan, Agus, 2015. Evaluasi Kinerja Sumber Daya Manusia,Teori Aplikasi dan penelitian, Salemba Empat, Jakarta. 


\section{Profil Penulis :}

1. Eva Amalia, Sekolah Tinggi Ilmu Manajemen Indonesia (STIMI) Banjarmasin. Email : evastimi@gmail.com

2. Drs. Muhammad Rudiansyah, MM, Dosen Sekolah Tinggi Ilmu Manajemen Indonesia (STIMI) Banjarmasin.

Email : rudibanper@gmail.com 